\title{
Long-term aerosol optical hygroscopicity study at the ACTRIS SIRTA observatory: synergy between ceilometer and in situ measurements
}

\author{
Andrés Esteban Bedoya-Velásquez ${ }^{1,2,3}$, Gloria Titos ${ }^{1,2,4}$, Juan Antonio Bravo-Aranda ${ }^{1,2}$, Martial Haeffelin ${ }^{5}$, \\ Olivier Favez ${ }^{6}$, Jean-Eudes Petit ${ }^{7}$, Juan Andrés Casquero-Vera ${ }^{1,2}$, Francisco José Olmo-Reyes ${ }^{1,2}$, \\ Elena Montilla-Rosero $^{8}$, Carlos D. Hoyos ${ }^{9,10}$, Lucas Alados-Arboledas ${ }^{1,2}$, and Juan Luis Guerrero-Rascado ${ }^{1,2}$ \\ ${ }^{1}$ Andalusian Institute for Earth System Research (IISTA-CEAMA), University of Granada, Autonomous Government of \\ Andalusia, Granada, Spain \\ ${ }^{2}$ Departament of Applied Physics, University of Granada, Granada, Spain \\ ${ }^{3}$ Sciences Faculty, Department of Physics, Universidad Nacional de Colombia, Medellín, Colombia \\ ${ }^{4}$ Institute of Environmental Assessment and Water Research (IDAEA), CSIC, Barcelona, Spain \\ ${ }^{5}$ Institut Pierre Simon Laplace, École Polytechnique, CNRS, Université Paris-Saclay, Palaiseau, France \\ ${ }^{6}$ Institut National de l'Environnement Industriel et des Risques, Parc Technologique ALATA, \\ 60550 Verneuil-en-Halatte, France \\ ${ }^{7}$ Laboratoire des Sciences du Climat et de l'Environnement (LSCE), CEA/Orme des Merisiers, 91191 Gif-sur-Yvette, France \\ ${ }^{8}$ Physical Sciences Department, School of Science, EAFIT University, Medellín, Colombia \\ ${ }^{9}$ Facultad de Minas, Departamento de Geociencias y Medio Ambiente, Universidad Nacional de Colombia, \\ Medellín, Colombia \\ ${ }^{10}$ Sistema de Alerta Temprana de Medellín y el Valle de Aburrá (SIATA), Área Metropolitana del Valle de Aburrá (AMVA), \\ Medellín, Colombia
}

Correspondence: Andrés Esteban Bedoya Velásquez (aebedoyav@correo.ugr.es)

Received: 6 January 2019 - Discussion started: 4 March 2019

Revised: 14 May 2019 - Accepted: 24 May 2019 - Published: 13 June 2019

\begin{abstract}
An experimental setup to study aerosol hygroscopicity is proposed based on the temporal evolution of attenuated backscatter coefficients from a ceilometer colocated with an instrumented tower equipped with meteorological sensors at different heights. This setup is used to analyze a 4.5-year database at the ACTRIS SIRTA observatory in Palaiseau (Paris, France, $2.208^{\circ}$ E, $48.713^{\circ} \mathrm{N} ; 160 \mathrm{~m}$ above sea level). A strict criterion-based procedure has been established to identify hygroscopic growth cases using ancillary information, such as online chemical composition, resulting in 8 hygroscopic growth cases from a total of 107 potential cases. For these eight cases, hygroscopic growth-related properties, such as the attenuated backscatter enhancement factor $f_{\beta}(\mathrm{RH})$ and the hygroscopic growth coefficient $\gamma$, are evaluated. This study shows that the hygroscopicity parameter $\gamma$ is negatively correlated with the aerosol organic mass fraction but shows a positive correlation with the aerosol in-
\end{abstract}

organic mass fraction. Among inorganic species, nitrate exhibited the highest correlation.

This is the first time that hygroscopic enhancement factors are directly retrieved under ambient aerosols using remotesensing techniques, which are combined with online chemical composition in situ measurements to evaluate the role of the different aerosol species in aerosol hygroscopicity.

\section{Introduction}

The role of natural and anthropogenic aerosol particles and greenhouse gases in the climate system has been deeply studied to evaluate the radiative forcing effect on the Earth's surface temperature (Twomey, 1977; Albrecht, 1989). The two major processes of aerosol interactions include (i) the 
aerosol-radiation interaction (ARI), which produces a direct effect on the Earth's radiative fluxes mainly by scattering and absorbing radiation, and (ii) the aerosol-cloud interaction (ACI) associated with changes in cloud properties and precipitation given that particles can act as cloud condensation nuclei (CCN) and ice nuclei (IN) (Boucher et al., 2013). Both interactions result in a net radiative effect on the global energy budget.

A key factor associated with aerosol radiative forcing is the so-called aerosol hygroscopicity, which is the capacity of particles to uptake water from the environment, changing both the size and chemical composition and thereby influencing the optical properties of aerosols. The magnitude of scattering enhancement depends on the aerosol chemical composition and size, and can be quantified by the hygroscopic enhancement factor $f_{\xi}^{\lambda}(\mathrm{RH})$ where $\xi$ refers to an opti$\mathrm{cal} /$ microphysical property (i.e., backscatter coefficient) and $\lambda$ is the wavelength. This factor is defined as the ratio between the optical/microphysical property under certain RH conditions and the optical/microphysical property under dry conditions within the volume of atmosphere selected. These studies have been performed using in situ setups, such as humidrograph tandem nephelometers and the Humidified Tandem Differential Mobility Analyzer (HTDMA) (e.g., Hänel, 1976; Zieger et al., 2011; Titos et al., 2016) as well as remotesensing instrumentation (e.g., Pilinis and Pandis, 1995; Ferrare et al., 1998; Feingold and Morley, 2003; Veselovskii et al., 2009; Granados-Muñoz et al., 2015; Bedoya-Velásquez et al., 2018, and references therein). Regarding the in situ setups, there are studies such as Titos et al. (2014a), Zhang et al. (2015), and Zieger et al. (2014) which deeply evaluate the hygroscopic growth properties and their relationship with organic and inorganic chemical composition, showing a decreasing tendency between $f(\mathrm{RH})$ and organic aerosols $(\mathrm{OA})$ and an increasing tendency between $f(\mathrm{RH})$ and inorganic aerosols (IA), allowing us to evaluate the role of organic and inorganic aerosol in hygroscopic growth studies. These results can be used in global climate models to better constrain aerosol hygroscopic properties with the local and regional emissions. Finally, fewer studies have been performed by crossing information between remote-sensing and in situ setups. In Lv et al. (2017) these synergies present interesting approaches for comparing chemical concentrations with hygroscopic growth properties mainly retrieved from lidar and radiosonde vertical cases studied, and good results have also been obtained in Rosati et al. (2016) by comparing aerosol hygroscopic growth properties such as $f(\mathrm{RH})$ between airborne in situ setups and ground-based remote sensing instruments.

One of the most used in situ variables for quantifying the diameter increase due to water uptake is the hygroscopic growth factor $g(\mathrm{RH})$ measured with a HTDMA (e.g., Swietlicki et al., 2008). Other instrumentation is used to directly determine the impact of water uptake on aerosol optical properties, such as humidrograph tandem nephelome- ters that measure the change in scattering coefficient with RH from dry (20\%-40\%) to wet conditions (up to $90 \%$ ) (e.g., Covert et al., 1972; Titos et al., 2016). To quantify the enhancement factor in airborne platforms, instruments, such as the Differential Aerosol Sizing and Hygroscopicity Spectrometer Probe (DASH-SP) (Sorooshian et al., 2008) or the white-light humidified optical particle spectrometer (WHOPS) (Rosati et al., 2015), have been used. A drawback of in situ techniques is the eventual modification of the aerosol properties due to the sampling of atmospheric aliquots by drying and wetting the air sample. Remotesensing techniques are able to overcome this limitation since they examine particles directly in the atmosphere without any modification of the air sample. Previous remote-sensing studies have combined lidars and radiosonde measurements (e.g., Ferrare et al., 1998; Granados-Muñoz et al., 2015; Fernández et al., 2015) and Raman lidars and microwave radiometer (MWR) data (Navas-Guzmán et al., 2014; BedoyaVelásquez et al., 2018) to investigate aerosol hygroscopic growth. Despite their promising capabilities, most of the lidar systems do not operate continuously due to the cost and maintenance requirements; thus, the number of hygroscopic growth cases explored is typically small (Vesolovskii et al., 2009; Granados-Muñoz et al., 2015; Fernández et al., 2018; Bedoya-Velásquez et al., 2018). Unlike sophisticated lidars, automatic lidars and ceilometers (ALCs) are robust systems designed for 24/7 automatic operations. In particular, Vaisala ceilometers have a reduced overlap height with respect to lidars, overcoming the near field of view limitation (Kotthaus et al., 2016).

Haeffelin et al. (2016) demonstrated that an experimental setup combining ceilometer and meteorological measurements from an instrumented tower could be used to forecast fog events, detecting the hygroscopic growth that precedes fog formation. This experimental setup together with ground-based aerosol in situ measurements is used in this study to optimize the selection of hygroscopic growth cases. This methodology is applied to a 4.5 -year database of continuous measurements performed at the ACTRIS SIRTA observatory in southern Paris (France). The relationship between the attenuated backscatter $\beta^{\text {att }}$ enhancement factor and submicron aerosol chemical composition is also investigated.

\section{Measurement site and instrumentation}

\subsection{Measurement site}

Measurements used in this study were performed at the SIRTA observatory (Site Instrumental de Recherche par Télédétection Atmosphérique, http://sirta.ipsl.fr/, last access: 25 May 2019) located approximately $20 \mathrm{~km}$ southwest of the Paris city center on the Saclay plateau $\left(2.208^{\circ} \mathrm{E}, 48.713^{\circ} \mathrm{N}\right.$; $160 \mathrm{~m}$ a.s.l.). This "supersite" is surrounded by suburban facilities, forests, agricultural fields, and roads connecting to 
Paris. It is part of the European Research Infrastructure for the observation of Aerosol, Clouds, and Trace gases (ACTRIS) and EARLINET (Pappalardo et al., 2014), including active and passive remote-sensing instrumentation operating since 2002 (Haeffelin et al., 2005) and in situ equipment operating continuously since 2011 (Petit et al., 2015). Atmospheric composition measurements performed at SIRTA are considered to be representative of background conditions for the Paris region. Regarding seasonal features, the winter and early spring periods frequently experience pollution episodes mainly related to wood burning and mobile sources (road transportation), and agricultural emissions at a regional scale along with the transport of polluted air masses are associated with high-pressure mesoscale systems (Petit et al., 2014, 2015; Dupont et al., 2016). During summer and autumn, the region remains clean; nevertheless, a maximum impact of road traffic emissions on air quality is noted during the September-October period (Petit et al., 2015).

\subsection{Meteorological and in situ aerosol measurements}

The meteorological instruments used in this study are located on an instrumented tower at 1, 2, 5, 10, 20, and $30 \mathrm{~m}$ a.g.l. (zone 4, http://sirta.ipsl.fr/documents/ressources/ SIRTA_reglementinterieur_2016_Annexe3.pdf, last access: 25 May 2019; see Fig. 1) described in Haeffelin et al. (2016). Here, we use meteorological measurements at $30 \mathrm{~m}$ a.g.l. and ceilometer (Vaisala CL31) measurements. Temperature and relative humidity were obtained from Young 41382 and 43408 sensors with a temporal resolution of $1 \mathrm{~min}$. Wind velocity and direction were measured using a sonic anemometer (Metec sonic anemometers) operating at $10 \mathrm{~Hz}$ for raw data $\left(1 \mathrm{~min}\right.$ averaged) with uncertainties of $0.1 \mathrm{~m} \mathrm{~s}^{-1}$ and $\pm 2^{\circ}$ for speed and direction, respectively.

Aerosol chemical composition of non-refractory submicron aerosols was obtained with an Aerosol Chemical Speciation Monitor (ACSM, Aerodyne Research, Inc.). A detailed description of measurement principles of this instrument can be found in $\mathrm{Ng}$ et al. (2011). Briefly, it notably allows measurements of concentrations of major submicron chemical species, including organic aerosol (OA), ammonium $\left(\mathrm{NH}_{4}^{+}\right)$, nitrate $\left(\mathrm{NO}_{3}^{-}\right)$, and sulfate $\left(\mathrm{SO}_{4}^{2-}\right)$ particles, with a temporal resolution of $30 \mathrm{~min}$ using online thermal desorption electron impact aerosol mass spectrometry. Black carbon (BC) mass concentration was obtained from measurements of the absorption coefficient at $880 \mathrm{~nm}$ performed with a multiwavelength aethalometer (AE33 model, Magee Scientific) at 1 min resolution. The AE33 measurement principle is described in Drinovec et al. (2015). In the present study, concentrations of $\mathrm{BC}$ and non-refractory chemical species are used as hourly data, and $\mathrm{PM}_{1}$ mass concentration is estimated as the sum of these compounds. Both ACSM and AE33 measurements are subject to ACTRIS (http://www.actris.eu, last access: 25 May 2019) quality control and quality assurance procedures, notably par- ticipating in regular intercomparison exercises at the $\mathrm{Eu}-$ ropean Center for Aerosol Calibration (e.g., https://www. actris-ecac.eu/files/ECAC-report-AP-2017-4-2.pdf, last access: 25 May 2019; Crenn et al., 2015; Freney et al., 2019). A full description of the calibration and data treatment methods for both AE33 and ACSM used in the present study is presented by Petit et al. (2017, 2015). The in situ monitoring station is located $5 \mathrm{~km}$ east of the instrumented tower (SIRTA zone 5, Fig. 1b).

\subsection{Vaisala CL31 ceilometer}

A Vaisala CL31 ceilometer colocated with an instrumented tower is used in this study. Ceilometers have two principal advantages compared with more powerful lidar systems typically used for atmospheric research. Ceilometers can reach their full overlap height between 20 and $200 \mathrm{~m}$ and allow unattended 24/7 operation. CL31 ceilometers operate using the lidar's principle by emitting radiation towards the atmosphere at $910 \mathrm{~nm}$ on a mono-axial configuration with a repetition rate of $10 \mathrm{kHz}$ and high spatial and temporal resolution ( $15 \mathrm{~m}$ and $30 \mathrm{~s}$, respectively). The total backscattered signal $P(z, t)$ from the CL31, accounting for both the aerosol and molecular signature, is defined as follows:

$P(z, t)=\frac{1}{z^{2}} C(t) O(z, t) \beta(z, t) T^{2}(z, t) T_{\mathrm{wv}}^{2}(z, t)$,

where $z$ is the signal range, $t$ is the time, $O(z, t)$ is the overlap function, $C(t)$ is the calibration constant, $\beta(z, t)$ is the total backscatter coefficient due to particles and molecules, $T(z, t)$ is the attenuation due to particles and molecules, and $T_{\mathrm{wv}}(z, t)$ is the attenuation due to water vapor molecular absorption of the laser light at $910 \mathrm{~nm}$ (Wiegner and Gasteiger, 2015). Both transmittances are defined as follows:

$$
\begin{aligned}
& T\left(z_{1}, z_{2}, t\right)=\exp \left(-\int_{z_{1}}^{z_{2}} \alpha_{T}(z, t) \mathrm{d} z\right), \\
& T_{\mathrm{wv}}\left(z_{1}, z_{2}, t\right)=\exp \left(-\int_{z_{1}}^{z_{2}} \sigma_{\mathrm{a}, \mathrm{wv}}(z, t) \mathrm{d} z\right),
\end{aligned}
$$

where $\alpha_{T}$ is the total extinction coefficient, including the extinction due to particles $\left(\alpha_{\mathrm{par}}\right)$ and molecules $\left(\alpha_{\mathrm{mol}}\right) ; \sigma_{\mathrm{a} \text {,wv }}$ is the water vapor absorption coefficient in the atmosphere, and $z_{1}$ and $z_{2}$ define the region where the air volume of interest is located.

The attenuated backscatter is typically defined by the backscatter attenuated by particles and molecules as follows:

$\beta^{\text {att }}(z, t)=\beta(z, t) T^{2}(z, t)$.

Due to the wavelength of operation, the CL31 signal also includes the water vapor absorption resulting as follows: 


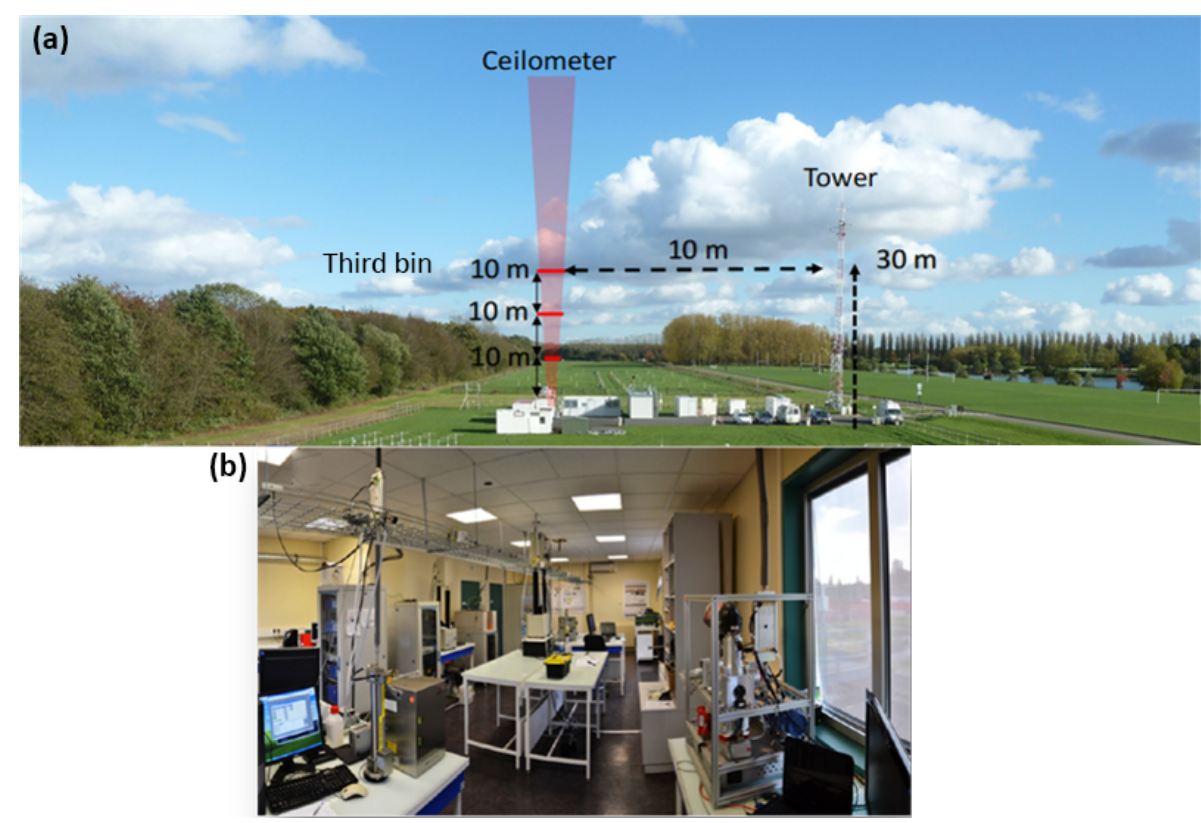

Figure 1. (a) Experimental setup (not $1: 1$ scale) for studying hygroscopic growth using the automatic instrumentation (ceilometer and hygrometer) and (b) in situ monitoring station at the ACTRIS SIRTA observatory.

$\beta_{\mathrm{wv}}^{\text {att }}(z, t)=\beta^{\text {att }}(z, t) T_{\mathrm{wv}}^{2}(z, t)=\frac{P(z, t) z^{2}}{C(t) O(z, t)}$.

The CL31 signal is affected by different aspects, such as external temperature variations and the geometry of the emission and reception systems (mainly linked with overlap) (Madonna et al., 2015). We assume the errors reported for $\beta^{\text {att }}$ coefficients are up to $10 \%$ or less following that reported by Wiegner and Geiß (2012).

\section{Methodology}

\subsection{Experimental setup}

Most of the studies investigating the effect of aerosol hygroscopicity on aerosol optical properties have focused on the particle scattering coefficient $\left(\sigma_{\mathrm{sp}}\right)$ measured with in situ techniques (e.g., Covert et al., 1972; Sorooshian et al., 2008; Zieger et al., 2011; Titos et al., 2016). More recently, remote-sensing measurements have been used to investigate aerosol hygroscopicity using the particle extinction coefficient (Veselovskii, et al., 2009) and particle backscattering coefficient (Granados-Muñoz, et al., 2015; Fernández et al., 2018; Bedoya-Velásquez et al., 2018). These studies use the enhancement factor $f_{\xi}(\mathrm{RH})$ defined as follows:

$f_{\xi}(\mathrm{RH})=\frac{\xi(\mathrm{RH})}{\xi\left(\mathrm{RH}_{\mathrm{ref}}\right)}$,

where $\xi$ represents an aerosol optical/microphysical property evaluated at certain $\mathrm{RH}$. $\mathrm{RH}_{\text {ref }}$ refers to a reference (dry) con- dition. The most common parameterization linking $f_{\xi}(\mathrm{RH})$ with RH was proposed by Hänel (1976):

$$
f_{\xi}(\mathrm{RH})=\left(\frac{1-\mathrm{RH} / 100}{1-\mathrm{RH}_{\mathrm{ref}} / 100}\right)^{-\gamma},
$$

where $\gamma$ parametrizes the aerosol hygroscopic enhancement (larger values of $\gamma$ are related to more hygroscopic aerosol particles).

To investigate aerosol hygroscopicity, we use the experimental setup proposed by Haeffelin et al. (2016) (Fig. 1) consisting of a Vaisala CL31 ceilometer colocated with a meteorological instrumented tower. This setup allows for simultaneous tracking of the $\beta_{\mathrm{wv}}^{\text {att }}$ and RH changes at $30 \mathrm{~m}$ a.g.l. $\left(z_{\text {ref }}\right)$. Thus, the attenuated backscatter enhancement factor affected by absorption of water vapor $f_{\beta_{\mathrm{wv}}}^{\text {att }}(\mathrm{RH})$ is expressed as follows:

$f_{\beta_{\mathrm{wv}}^{\text {att }}}(\mathrm{RH})=\frac{\beta_{\mathrm{wv}}^{\text {att }}\left(z_{\text {ref }}, t\right)}{\beta_{\mathrm{wv}}^{\text {att }}\left(z_{\mathrm{ref}}, t_{\mathrm{d}}\right)}=\frac{\beta^{\text {att }}\left(z_{\mathrm{ref}}, t\right) T_{\mathrm{wv}}^{2}\left(z_{\mathrm{ref}}, t\right)}{\beta^{\text {att }}\left(z_{\mathrm{ref}}, t_{\mathrm{d}}\right) T_{\mathrm{wv}}^{2}\left(z_{\mathrm{ref}}, t_{\mathrm{d}}\right)}$,

where $t_{\mathrm{d}}$ refers to the dry state of the aerosols within the temporal window of evaluation. Then, replacing from Eq. (5), the following formula is obtained:

$f_{\beta_{\mathrm{wv}}^{\text {att }}}(\mathrm{RH})=\frac{P\left(z_{\mathrm{ref}}, t\right) z_{\mathrm{ref}}^{2} / C(t) O\left(z_{\mathrm{ref}}, t\right)}{P\left(z_{\mathrm{ref}}, t_{\mathrm{d}}\right) z_{\mathrm{ref}}^{2} / C\left(t_{\mathrm{d}}\right) O\left(z_{\mathrm{ref}}, t_{\mathrm{d}}\right)}$.

Assuming that the calibration factor and the overlap function are sufficiently stable during the period considered, the attenuated backscatter enhancement factor affected by absorption of water vapor can be expressed as follows:

$f_{\beta_{\mathrm{wv}}^{\text {att }}}(\mathrm{RH})=\frac{P\left(z_{\mathrm{ref}}, t\right)}{P\left(z_{\mathrm{ref}}, t_{\mathrm{d}}\right)}$. 
Thus, we can directly retrieve $f_{\beta_{\mathrm{wv}}}$ (RH). Finally, we need to estimate the transmittance ratio due to the water vapor absorption to determine $f_{\beta}$ att as follows:

$f_{\beta^{\text {att }}}(\mathrm{RH})=f_{\beta_{\mathrm{wv}}^{\text {att }}}(\mathrm{RH}) \frac{T_{\mathrm{wv}}^{2}\left(z_{\mathrm{ref}}, t_{\mathrm{d}}\right)}{T_{\mathrm{wv}}^{2}\left(z_{\mathrm{ref}}, t\right)}$.

The water vapor term can be rewritten using Eq. (3):

$\frac{T_{\mathrm{wv}}^{2}\left(t_{\mathrm{d}}\right)}{T_{\mathrm{wV}}^{2}(t)}=\exp \left(-\int_{z_{1}}^{z_{2}}\left(\sigma_{\mathrm{a}, \mathrm{wv}}\left(t_{\mathrm{d}}\right)-\sigma_{\mathrm{a}, \mathrm{wv}}(t)\right) \mathrm{d} z\right)$,

where the dependence of height has been omitted for the sake of clarity. Following Wiegner and Gasteiger (2015), the extinction coefficient due to water vapor absorption is given as follows:

$\sigma_{\mathrm{a}, \mathrm{wv}}(t)=n_{\mathrm{wv}}(t) \sigma_{\mathrm{wv}}=7.25 \times 10^{22} q(t) R_{\mathrm{wv}} \sigma_{\mathrm{wv}}$,

where $\sigma_{\mathrm{wv}}$ is the water vapor absorption cross section and $n_{\mathrm{wv}}(t)$ refers to the water vapor concentration. $R_{\mathrm{wv}}=$ $0.462 \mathrm{~J} \mathrm{~g}^{-1} \mathrm{~K}^{-1}$ is the gas constant of water vapor and $q$ is the absolute humidity. For this evaluation, we assume that $\sigma_{\mathrm{wv}}=2.4 \times 10^{-22} \mathrm{~cm}^{2}$ is simulated at $908.957 \mathrm{~nm}$ (Wiegner and Gasteiger, 2015; Wiegner et al., 2019). Then, replacing Eq. (13) with Eq. (12), we obtain the following:

$$
\begin{aligned}
\frac{T_{\mathrm{wv}}^{2}\left(t_{\mathrm{d}}\right)}{T_{\mathrm{wv}}^{2}\left(t_{\mathrm{w}}\right)} & =\exp \left(-2 \int_{z_{1}}^{z_{2}}\left(\sigma_{\mathrm{a}, \mathrm{wv}}\left(t_{\mathrm{d}}\right)-\sigma_{\mathrm{a}, \mathrm{wv}}(t)\right) \mathrm{d} z\right) \\
& =\exp \left(-2 K_{\mathrm{wv}} \int_{z_{1}}^{z_{2}}\left(q\left(t_{\mathrm{d}}\right)-q(t)\right) \mathrm{d} z\right) \\
& =\exp \left(-2 K_{\mathrm{wv}} \Delta q \Delta z\right),
\end{aligned}
$$

where $K_{\mathrm{wv}}$ gathers all the constants, such as $\sigma_{\mathrm{wv}}, R_{\mathrm{wv}}, \Delta z$ (30 m a.g.l. in our instrument setup), and $\Delta q=q\left(t_{\mathrm{d}}\right)-q(t)$. An important fact shown in Eq. (14) is that water vapor correction is only affected by the relative difference of the absolute humidity in the explored temporal frame. The setup used allows us to obtain the experimental value of $q(t)$ to perform the calculation proposed in Eq. (14).

Once the $f_{\beta}$ att $(\mathrm{RH})$ is obtained, we must address the fact that $\beta^{\text {att }}$ is influenced by the transmittance of the atmospheric layer between the surface and $30 \mathrm{~m}$. In this regard, the link between the attenuated backscatter coefficient $\left(\beta^{\text {att }}\right)$ and particle backscatter coefficient $(\beta)$ at $30 \mathrm{~m}$ was evaluated in detail in Haeffelin et al. (2016) to guarantee the suitability of using the attenuated backscatter for hygroscopicity studies. Indeed, Haeffelin et al. (2016) found that differences between $f_{\beta}$ att $(\mathrm{RH})$ and the particle backscatter enhancement factor $f_{\beta}(\mathrm{RH})$ to be lower than $10 \%$ by assuming a lidar ratio between 30 and $80 \mathrm{sr}$ (at $\mathrm{RH}_{\text {ref }}$ ) in the simulations and $f_{\alpha}(\mathrm{RH})>f_{\beta^{a t t}}(\mathrm{RH})$. Therefore, in the paper, we will assume hereafter that $f_{\beta}$ att $(\mathrm{RH}) \cong f_{\beta}(\mathrm{RH})$; therefore, $\beta^{\text {att }}$ will be treated as $\beta$ from this point forward.
Additionally, to make this study comparable with most applied in situ approaches, we performed the calculation of $f_{\beta}(\mathrm{RH})$ using two approaches. The first approach considers the $\mathrm{RH}_{\mathrm{ref}}$ to be the lower value of $\mathrm{RH}$ in the atmosphere within the time window of evaluation, and the second approach takes an extrapolation of the $f_{\beta}(\mathrm{RH})$ to $\mathrm{RH}_{\text {ref }}=40 \%$, assuming such a value of $\mathrm{RH}_{\text {ref }}$ to be the driest one in the atmosphere. This second approach becomes important only because this work aims to be compared with in situ studies. An important fact of this extrapolation is that it uses the same $\gamma$ parameter; therefore, the same aerosol is studied. The $\mathrm{RH}_{\text {ref }}$ extrapolated values presented percentage differences greater than those found in this study, suggesting that theoretically the aerosol should be dry at lower RH than the atmosphere shown; however, atmosphere takes into account different processes that surely modify the theoretical extrapolated $\mathrm{RH}_{\mathrm{ref}}$ found.

\subsection{Data preprocessing and uncertainties estimation}

To homogenize the different datasets, CL31 measurements were averaged to the same temporal resolution as RH measurements (i.e., $1 \mathrm{~min})$. Then, $f_{\beta}(\mathrm{RH})$ was determined using Eq. (6) to retrieve $\gamma$ using Eq. (7). The error associated with $\gamma$ was calculated using the Monte Carlo technique, modeling raw measurements of $\beta$ and $\mathrm{RH}$ as the normal distributions and $\beta_{\text {ref }}$ and $\mathrm{RH}_{\text {ref }}$ as the respective values calculated for each case and finally assuming the error as the mean standard deviation of all simulations. The uncertainty of $f_{\beta}(\mathrm{RH})$ was also estimated using the Monte Carlo technique by using the values of $\gamma$ found and the same modeling previously performed for $\beta$ and $\mathrm{RH}$. The estimated error of applying the water vapor correction to $\beta^{\text {att }}$ was obtained as the bias between $\beta^{\text {att }}$ and $\beta_{\mathrm{wv}}^{\text {att }}$ for the cases studied, which is less than $2.5 \times 10^{-7} \mathrm{~m}^{-1} \mathrm{sr}^{-1}$ (see the Supplement for further details). The uncertainty of this correction was also calculated using the Monte Carlo technique by applying Eq. (7), modeling $\beta^{\text {att }}$ and $T_{\mathrm{wv}}^{2}$ as a normal distribution and running this procedure 10000 times. With this procedure, we obtained an error of approximately $3.0 \times 10^{-7} \mathrm{~m}^{-1} \mathrm{sr}^{-1}$. It is important to mention that the use of this methodology could lead to larger uncertainties than those reported in previous in situ or collocated lidar hygroscopic studies, which are mostly associated with instrumental error propagation.

\subsection{Aerosol hygroscopic optical enhancement identification}

The main challenge when dealing with real (i.e., uncontrolled) atmospheric conditions is the ability to isolate the hygroscopic enhancement effect from all other processes that occur simultaneously (changes in air masses, emissions, or advected aerosol particles from local sources). Therefore, we designed a methodology to (i) identify potential hygroscopic enhancement events when there is an observed increase in 
the attenuated backscatter coefficient simultaneously to an increase in ambient RH and to (ii) elucidate whether those increases are due to hygroscopic growth. To evaluate these conditions, we propose four phases in which different instrumentation is involved with the aim of extending its applicability depending on the instrument availability.

Phase 1. Preprocessing of ceilometer data. This step includes the corrections mentioned in Sect. 3.1 as well as the water vapor correction explained in Sect. 3.2. Additionally, the data are averaged in $1 \mathrm{~min}$ intervals.

Phase 2. Selection of potential hygroscopic growth cases. Potential cases have been selected by looking for simultaneous increases/decreases in $\beta$ and ambient RH. To this end, a 3 to $5 \mathrm{~h}$ sliding temporal window has been used. Time windows larger than $5 \mathrm{~h}$ are avoided to minimize the influence of changing emission sources and air masses.

Phase 3. Hänel parameterization of potential cases. After applying Hänel parameterization (Eq. 7), we select only those cases that fulfill the following.

1. $R^{2}>0.80$, ensuring high data correlation following Hänel parameterization.

2. $\Delta \mathrm{RH}>30 \%$, where $\Delta \mathrm{RH}$ refers to the difference between final and initial RH within the temporal window under study. This criteria is used to apply the Hänel parameterization over a sufficient $\mathrm{RH}$ range.

3. $\mathrm{RH}_{\text {ref }}<60 \%$ allow us to choose the driest $\beta_{\text {ref }}$ without losing potential hygroscopic growth cases.

4. The analysis is restricted to $\mathrm{RH}<99 \%$ to avoid air masses with $\mathrm{RH}=100 \%$ or those that are supersaturated.

5. Low variability $(<35 \%)$ in both wind speed and direction. Based on the analysis of wind speed $W_{\mathrm{s}}(t)$ and wind direction $W_{\mathrm{d}}(t)$, this criterion aims to minimize the impact of changing air masses during the time window under evaluation. Numerically, this variability is calculated by dividing the standard deviation by the mean value.

Phase 4. Additional information on aerosol concentration is needed to discard the notion that the increase observed in $\beta$ is not related to an increase in the aerosol mass concentration but to an increase in RH. In our case, we used data from the ACSM and aethalometer given the advantage that we can specifically assess aerosol chemical components. In this step of the methodology, we define the ratio index (RI) as the ratio between $f_{\beta}(\mathrm{RH})$ and $f_{\mathrm{PM}_{1}}(\mathrm{RH})$, in order to evaluate whether the increase in $\beta$ is associated with an increase in the aerosol load. Therefore, we rejected those potential hygroscopic enhancement cases that showed $\mathrm{RI}<0.5$.

After applying the aforementioned methodology to 4.5 years of continuous measurements at the ACTRIS SIRTA observatory (from 1 January 2012 to 19 June 2016), we iden- tified 107 potential cases of aerosol hygroscopicity enhancement (phases 1 and 2). The number of hygroscopic growth cases fulfilling (3.i) and (3.ii) was reduced to 64 cases. Continuing with the phases proposed here, once we performed the following steps (3.iii, 3.iv, 3.v, and phase 4), we obtained eight cases in which we can ensure that the enhancement in the attenuated backscatter coefficient is due to aerosol hygroscopicity. Despite the significant reduction in the number of hygroscopic growth cases from the 107 initial potential cases, the methodology presented here allowed us to disregard those cases in which the enhancement can be attributed to increase in $\mathrm{RH}$ or changing aerosol type or load. This is the first time that remote-sensing-derived aerosol hygroscopicity has been investigated in such detail thanks to the availability of colocated in situ measurements. The eight cases identified are analyzed in detail in the following section.

\section{Results and discussion}

\subsection{Two case studies of the methodology implementation}

As an example of the methodology implementation, this section shows two of the final eight hygroscopic growth cases found in this study (Figs. 2 and 3). These examples correspond to 25 June 2013 from 07:17 to 10:17 UTC (case 3) and 17 May 2016 from 07:40 to 10:40 UTC (case 8). Figures $2 \mathrm{a}$ and $3 \mathrm{a}$ present the time evolution of $\beta, T, \mathrm{RH}$, $q, W_{\mathrm{s}}, W_{\mathrm{d}}$, dew point temperature $T_{\mathrm{d}}$, and $1 \mathrm{~h}$ averaged aerosol chemical composition (BC, $\mathrm{OA}, \mathrm{NH}_{4}^{+}, \mathrm{NO}_{3}^{-}$, and $\mathrm{SO}_{4}^{2-}$ ). The shadowed regions in Figs. 2a and 3a highlight the selected time window in which $\beta$ and $\mathrm{RH}$ simultaneously increase/decrease. Figures $2 \mathrm{~b}$ and $3 \mathrm{~b}$ show $f_{\beta}(\mathrm{RH})$ and $f_{\mathrm{PM}_{1}}(\mathrm{RH})$, and Figs. 2c and $3 \mathrm{c}$ contain a pie chart with the mean contribution of each chemical compound during the hygroscopic event. These cases were selected to show two different situations found in this study (the other six cases are shown in Figs. S5-S10 of the Supplement). Once a simultaneous monotonic decrease was observed for $\beta$ and $\mathrm{RH}$ in cases 3 and 8, we applied the Hänel parameterization, obtaining the corresponding $\gamma$ and $f_{\beta}(\mathrm{RH}=85 \%)$.

Case 3 presents the lower value of the hygroscopicity parameter, with values of $\gamma=0.5 \pm 0.4$ and $f_{\beta}(\mathrm{RH}=85 \%)=$ $1.7 \pm 0.2$. During case 3 , the predominant wind direction was northwesterly with relatively low wind speed $\left(W_{\mathrm{s}}=\right.$ $2.5 \mathrm{~m} \mathrm{~s}^{-1}$ ) and some variability up to $\Delta W_{\mathrm{s}}=24.5 \%$ and $\Delta W_{\mathrm{d}}=33.9 \%$, and the chemical composition was relatively constant in most compounds over the time window studied. The average chemical composition (Fig. 2c) indicated a high contribution of $\mathrm{OA}(58 \%)$ and $\mathrm{BC}(17 \%)$ particles, and the total aerosol mass $\left(\mathrm{PM}_{1}\right)$ was almost constant during the hygroscopic case (from 07:17 to 10:17 UTC), showing no correlation with $\mathrm{RH}$. The relatively high presence of $\mathrm{BC}$ and $\mathrm{OA}$ (less hygroscopic compounds) may reduce the hygroscopic- 
(a)

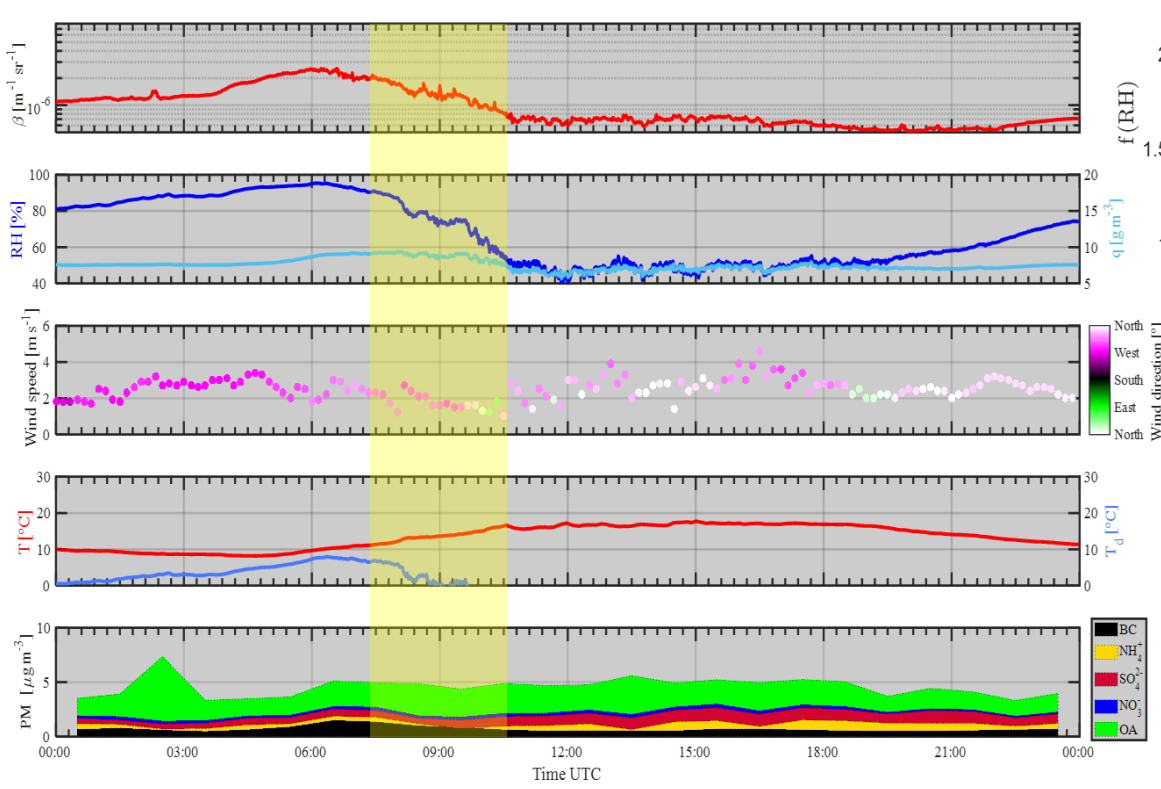

(b)

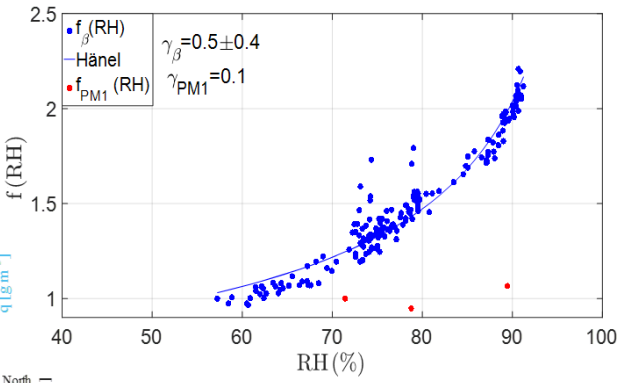

(c)

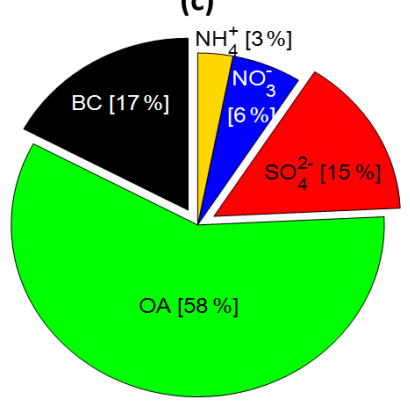

Figure 2. Case 3 on 25 June 2013: (a) time series of $\beta$ (relative humidity, $\mathrm{RH}$; absolute humidity, $q$; wind speed, $W_{\mathrm{s}}$; wind direction, $W_{\mathrm{d}}$; temperature, $T$; dew point temperature, $\left.T_{\mathrm{d}}\right)$ and $\mathrm{PM}_{1}$ chemical species concentration according to the legend; $(\mathbf{b}) \mathrm{PM}_{1}$-related $f_{\mathrm{PM}_{1}}(\mathrm{RH})$ and $\beta$-related $f_{\beta}(\mathrm{RH})$; and (c) pie chart of the chemical composition. Panels (b) and (c) are measured for the hygroscopic event time window. The highlighted region in yellow (from 07:17 to 10:17 UTC) represents the time window when the aerosol hygroscopic growth is evaluated.

(a)
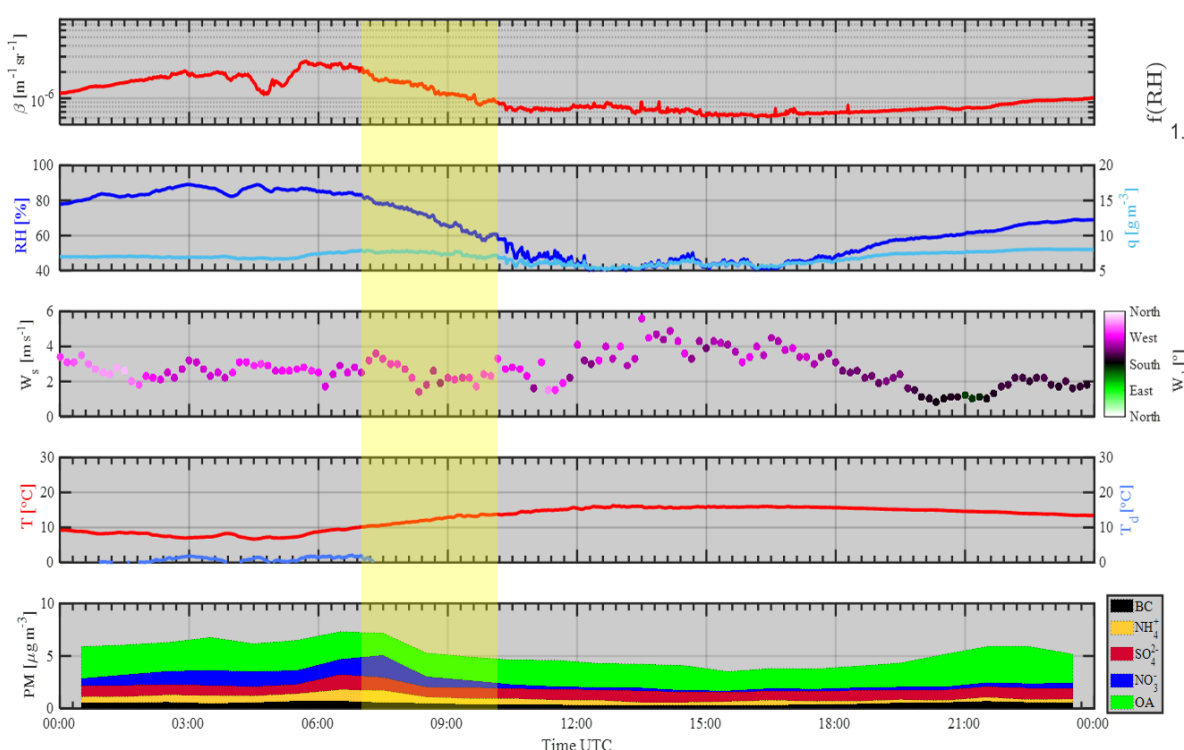

(b)

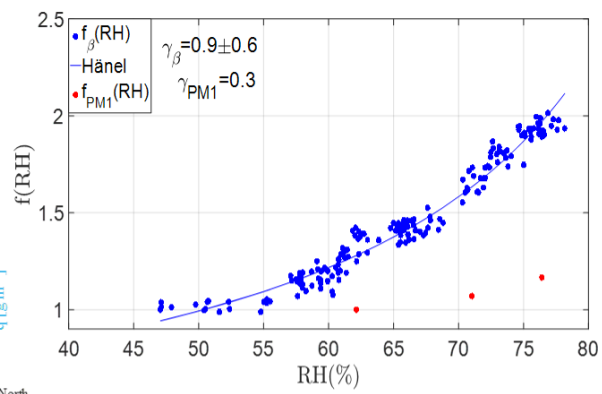

(c)

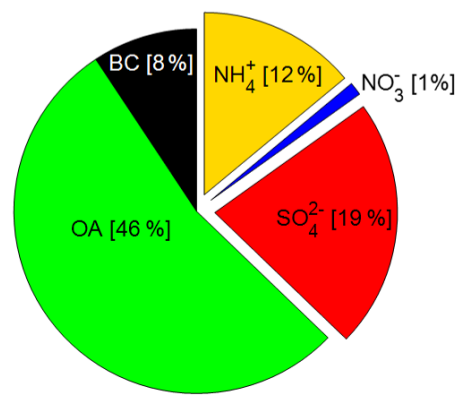

Figure 3. As noted in Fig. 2 but using case 8 on 17 May 2016 with the highlighted region from 07:40 to 10:40 UTC. 
ity properties. These findings are consistent with results from rural and suburban sites presented by Chen et al. (2014) in Wuqing (China), Zieger et al. (2014) in Melpitz (Germany), and Titos et al. (2014a) in Granada (Spain), where low values of hygroscopicity parameters were observed due to high contributions of $\mathrm{OA}$ and $\mathrm{BC}$. A detailed discussion of the origin of the air masses will be given in Sect. 4.2.

Case 8 presents predominant westerly wind with a relatively high mean wind speed $\left(5 \mathrm{~m} \mathrm{~s}^{-1}\right)$ and low variability in both wind speed and wind direction $\left(\Delta W_{\mathrm{s}}=20.7 \%\right.$ and $\Delta W_{\mathrm{d}}=6.4 \%$ ), and a slight increase in $\mathrm{PM}_{1}$ with $\mathrm{RH}$ was observed (Fig. 3b). However, the enhancement of $\beta$ is significantly higher with respect to the variation in $\mathrm{PM}_{1}$. In fact, the RI remains within the selected range $(R I=0.60)$, denoting that most of the increase in the attenuated backscatter coefficient can be attributed to hygroscopic growth. The chemical composition during case 8 shows a predominance of OA (46\%) but also with important contribution of secondary inorganic compounds $\mathrm{SO}_{4}^{2-}(19 \%)$ and $\mathrm{NH}_{4}^{+}(12 \%)$, which are highly hygroscopic, and low contribution of $\mathrm{BC}$ $(8 \%)$. This case exhibited higher aerosol hygroscopic properties than case 3 with $\gamma=0.9 \pm 0.6$ and $f_{\beta}(\mathrm{RH}=85 \%)=$ $2.5 \pm 0.3$. This behavior might be linked to the lower contribution of $\mathrm{OA}$ and $\mathrm{BC}$ and higher contribution of inorganic aerosols (IA). Studies performed close to the SIRTA site by Randriamiarisoa et al. (2006) at Saclay (France) report a high $\gamma=1.04$ and $f_{\sigma}(\mathrm{RH}=80 \%) \sim 2.0$ linked to a low contribution of OA and high IA contribution associated with anthropogenic and marine aerosols. A more in-depth description of this case will be given in the following sections.

\subsection{Relationship between aerosol hygroscopicity properties and chemical composition}

Table 1 reports the eight aerosol hygroscopic growth cases found with the described methodology presented in Sect. 3.3 applied to the 4.5-year database. In general, most of the air masses (calculated by the HYSPLIT model, but not shown here) came from Canada, Greenland, and Iceland, passed through the Atlantic Ocean, and then crossed the United Kingdom before reaching France, therefore suggesting a mixture of marine aerosols with other types such as urban, anthropogenic, and other local sources found in this study. Three cases were observed in spring (case 6, case 7, and case 8), presenting relatively high concentrations of $\mathrm{SO}_{4}^{2-}$ and $\mathrm{NO}_{3}^{-}$with the exception of case 8 in which $\mathrm{NH}_{4}^{+}$was higher than $\mathrm{NO}_{3}^{-}$(case 6 with $11 \%\left(\mathrm{SO}_{4}^{2-}\right)$ and $21 \%\left(\mathrm{NO}_{3}^{-}\right)$, case 7 with $36 \%\left(\mathrm{SO}_{4}^{2-}\right)$ and $10 \%\left(\mathrm{NO}_{3}^{-}\right)$, and case 8 with $19 \%\left(\mathrm{SO}_{4}^{2-}\right)$ and $1 \%\left(\mathrm{NO}_{3}^{-}\right)$, respectively, with a high concentration of $\mathrm{NH}_{4}^{+}(12 \%)$ ). The high sulfate concentration in this season could be mainly related to the advection of air masses containing petrochemical and shipping emissions over this area and the typical increases in the nitrate and ammonia in spring that might be linked to the formation of par- ticulate ammonium nitrate from road transport and agricultural gaseous emission under favorable meteorological conditions (Petit et al., 2015). Four cases were found in summer (case 1 , case 3 , case 4 , and case 5), a period of the year commonly characterized by low wind speed at the ACTRIS SIRTA observatory (Petit et al., 2015), which reduces longrange transport of aerosol particles. Finally, a case was observed in September (case 2) showing the highest concentrations of $\mathrm{PM}_{1}$ up to $10 \mu \mathrm{g} \mathrm{m}^{-3}$ with a major presence of $\mathrm{OA}(56 \%), \mathrm{SO}_{4}^{2-}(18 \%)$, and $\mathrm{NH}_{4}^{+}(15 \%)$. All these cases occurred between 06:00 and 14:00 UTC when the temperature increased monotonically with almost constant absolute humidity; thus, RH decreased. In this area, the OA is considered to be a regional background component that dominates the $\mathrm{PM}_{1}$ chemical composition independently of the wind direction (Petit et al., 2015). According to previous studies, the higher concentrations of OA observed in this region might be associated with local influence, mainly in winter and autumn given the increase in wood burning and road traffic pollution (e.g., Zhang et al., 2007; Putaud et al., 2010; Petit et al., 2014, 2015).

Cases 2, 4, and 6 present values similar to the values reported by Fernández et al. $(2015)$ of $f_{\beta}(\mathrm{RH}=85 \%)=2.04$ with $\gamma=0.589 \pm 0.007$ at Cabauw station (Netherlands) using lidar measurements with the presence of marine salt particles, ammonium nitrate, and organic matter. The composition of these particles was linked to anthropogenic activities, oceanic air masses, and agriculture over this region. In addition, Fernández et al. (2018) found values of $f_{\beta}$ par $(\mathrm{RH}=85 \%)=2.05(\gamma=0.92 \pm 0.02)$ for marine particles based on measurements from the Madrid-CIEMAT station (Spain) that are close to the values of cases 7 and 8 in our study. These results from the literature are consistent with the predominant chemical composition found in our study. Case 5 exhibited relatively high concentrations of $\mathrm{SO}_{4}^{2-}(20 \%)$ and $\mathrm{OA}(58 \%)$, leading to $f_{\beta}(\mathrm{RH}=85 \%)=1.6 \pm 0.1(\gamma=$ $0.5 \pm 0.2)$. These values are comparable with those reported by Bedoya-Velásquez et al. (2018) for a mixture of anthropogenic and smoke particles at the IISTA-CEAMA station (Granada, Spain). Nevertheless, the values presented in this work are not fully comparable with previous remote-sensing literature since the $f_{\beta}(\mathrm{RH})$ is derived at $910 \mathrm{~nm}$, whereas most enhancement factor values in the literature are reported at $532 \mathrm{~nm}$. This fact would slightly change the efficiency of the backscatter cross sections of the aerosol particles analyzed; consequently, $f(\mathrm{RH}=85 \%)$ may also change. Another difference with most remote-sensing studies is that we studied the temporal change in the aerosol hygroscopicity (RH and $\beta$ ), while most studies investigate the vertical change.

The results obtained in this study can also be compared with previous studies based on in situ data, taking into account that the remote-sensing and in situ techniques have different working principles and the intrinsic difference of the optical property investigated (attenuated backscatter coeffi- 
Table 1. Enhancement factor $\left(f_{\beta}(\mathrm{RH}=85 \%)\right)$ at $\mathrm{RH}_{\text {ref }}$ of the case and extrapolated at $\mathrm{RH}_{\text {ref }}=40 \%, \gamma$, wind speed, variability of wind speed and wind direction, and the index of variability between $\Delta f_{\mathrm{PM}_{1}}$ and $\Delta f_{\beta}(\mathrm{RH})$. These variables are used to perform the analysis of the aerosol hygroscopic cases.

\begin{tabular}{|c|c|c|c|c|c|c|c|c|c|}
\hline & $\begin{array}{r}\mathrm{RH}_{\text {ref }} \\
(\%)\end{array}$ & $\begin{array}{r}\beta_{\text {ref }} \\
\left(\mathrm{m}^{-1} \mathrm{Sr}^{-1}\right)\end{array}$ & $f_{\beta}(\mathrm{RH}=85)$ & $f_{\beta}(\mathrm{RH}=85 / 40)$ & $\gamma$ & $\begin{array}{r}W_{\mathrm{S}} \\
\left(\mathrm{m} \mathrm{s}^{-1}\right)\end{array}$ & $\begin{array}{r}\Delta W_{\mathrm{S}} \\
(\%)\end{array}$ & $\begin{array}{r}\Delta W_{\mathrm{d}} \\
(\%)\end{array}$ & RI \\
\hline Case 1: 29 Jul 2012 & 52.9 & $6.2 \times 10^{-7}$ & $1.8 \pm 0.2$ & $2.3 \pm 0.2$ & $0.6 \pm 0.6$ & 1 & 14.2 & $3.6(\mathrm{~W})$ & 0.7 \\
\hline Case 2: 2 Sep 2012 & 49.6 & $6.6 \times 10^{-7}$ & $2.1 \pm 0.2$ & $2.6 \pm 0.2$ & $0.7 \pm 0.4$ & 2.5 & 20.7 & $23.0(\mathrm{NW})$ & 0.7 \\
\hline Case 3: 25 Jun 2013 & 57.3 & $9.1 \times 10^{-7}$ & $1.7 \pm 0.2$ & $2.0 \pm 0.2$ & $0.5 \pm 0.4$ & 2.5 & 24.5 & $33.9(\mathrm{NW})$ & 0.6 \\
\hline Case 4: 28 Jul 2014 & 53.7 & $5.1 \times 10^{-7}$ & $2.2 \pm 0.2$ & $2.6 \pm 0.2$ & $0.7 \pm 0.7$ & 5 & 15.4 & $2.7(\mathrm{~W})$ & 0.7 \\
\hline Case 5: 17 Aug 2014 & 56.7 & $4.1 \times 10^{-7}$ & $1.6 \pm 0.1$ & $2.0 \pm 0.1$ & $0.5 \pm 0.2$ & 5.5 & 20.4 & $2.4(\mathrm{SW})$ & 0.8 \\
\hline Case 6: 21 May 2015 & 55.1 & $6.7 \times 10^{-7}$ & $2.4 \pm 0.2$ & $3.0 \pm 0.2$ & $0.7 \pm 0.4$ & 2.5 & 18.5 & $4.4(\mathrm{~W})$ & 0.5 \\
\hline Case 7: 15 Apr 2016 & 51.6 & $8.6 \times 10^{-7}$ & $2.3 \pm 0.3$ & $3.0 \pm 0.3$ & $0.8 \pm 0.3$ & 6 & 10.9 & $1.7(\mathrm{SW})$ & 0.6 \\
\hline Case 8: 17 May 2016 & 47.1 & $7.2 \times 10^{-7}$ & $2.5 \pm 0.3$ & $3.3 \pm 0.3$ & $0.9 \pm 0.6$ & 3 & 20.7 & $6.4(\mathrm{~W})$ & 0.6 \\
\hline
\end{tabular}

cient and integrated scattering coefficient). Remote sensing operates under unmodified ambient conditions, and the optical property evaluated is $\beta$. In contrast, hygroscopic growth in situ measurements are performed by controlling RH (starting mostly from $\mathrm{RH}_{\mathrm{ref}}=40 \%$ ) and use $\sigma_{\mathrm{sp}}$ (scattering coefficient) as the optical property. Therefore, the results between techniques are not directly comparable. Thus, to make the studies more comparable, we performed an extrapolation of $f_{\beta}(\mathrm{RH}=85)$ to $40 \%$ which is the $\mathrm{RH}_{\text {ref }}$ mostly used in the in situ studies. The cases with lower hygroscopic properties in our study are cases 1,3 , and 5 , presenting $f_{\beta}(\mathrm{RH}=85 / 40 \%) \sim 2.3 \pm 0.2,2.0 \pm 0.2$, and $2.0 \pm 0.1$ with $\gamma=0.6 \pm 0.6, \gamma=0.5 \pm 0.4$ and $\gamma=0.5 \pm 0.2$, respectively. Similar values are reported for $f_{\sigma}(\mathrm{RH}=80 / 40 \%)$ and $f_{\sigma}(\mathrm{RH}=85 / 40 \%)$ at $\mathrm{RH}_{\text {ref }}=40 \%$ by Sheridan et al. (2002) in the Indian Ocean, Titos et al. (2014b) in Cape Cod (US), and Chen et al. (2014) in Wuqing (China) for polluted, marine, and mixed aerosols (urban and suburban) using in situ techniques. In this study, these three cases have low $\mathrm{NO}_{3}^{-}$concentrations and relative higher $\mathrm{OA}$ and $\mathrm{BC}$ concentrations, which highlight an aerosol mixture with the predominance of less hygroscopic particles compared with the other five cases. Cases 2, 4, 6, 7, and 8 presented similar values of $f_{\beta}(\mathrm{RH}=85 / 40 \%)$ ranging from 2.6 to 3.3, while $\gamma$ lay between $0.7<\gamma<0.9$, showing a higher $\mathrm{NO}_{3}^{-}$concentration with the exception of case 8 that exhibited higher concentrations of $\mathrm{SO}_{4}^{2-}$ and $\mathrm{NH}_{4}^{+}$. The $f_{\beta}(\mathrm{RH}=80 \%)$ and $\gamma$ values can be well compared to reported ones found in in situ studies performed by Kotchenruther et al. (1999) (East Coast, US) and Randriamiarisoa et al. (2006) (Saclay, France) that probed air masses influenced by anthropogenic and marine (clean and polluted) aerosols.

Table 2 presents the relationship between chemical composition and aerosol hygroscopicity. To this end, we calculated the organic mass fraction (OMF) defined as OA mass concentration divided by the total mass concentration $\left(\mathrm{PM}_{1}\right)$ and inorganic mass fraction (IMF) calculated as the IA divided by the total mass concentration. Figure $4 \mathrm{a}$ shows an anti-correlation between OMF and $\gamma(y=$ $\left.(-1.5 \pm 0.1) \times+(1.5 \pm 0.1), R^{2}=0.67\right)$, and Fig. $4 \mathrm{~b}$ shows that IMF exhibits a positive correlation with $\gamma(y=(1.2 \pm$ $\left.0.1) \times+(0.2 \pm 0.1), R^{2}=0.42\right)$. To compare both hygroscopic properties $(f(\mathrm{RH}=85)$ and $\gamma)$ with the in situ literature, we also performed a linearization of the $f(\mathrm{RH}=$ 85) extrapolated to $40 \%$ using this value as a reference for dry conditions, showing the same tendency for OMF ( $y=$ $\left.(-4.81 \pm 0.04) \times+(5.3 \pm 0.1), R^{2}=0.60\right)$ and IMF $(y=$ $\left.(3.8 \pm 0.1) \times+(1.1 \pm 0.1), R^{2}=0.40\right)$ but with higher slopes. These results are consistent with in situ studies that correlate the chemical composition with $f_{\sigma}(\mathrm{RH}=85 / 40)$ and $\gamma$, showing that aerosol hygroscopicity decreases as the relative contribution of OA in the total aerosol load increases (e.g., Kamilli et al., 2014; Zieger et al., 2014; Titos et al., 2014a; Zhang et al., 2015; Jefferson et al., 2017; Chen et al., 2018).

The slopes presented in Table 2 for $f_{\beta}(\mathrm{RH}=85 / 40 \%)$ versus OMF and IMF are in good agreement with the results expected according to the literature, showing a negative correlation of $f_{\beta}(\mathrm{RH}=85 / 40 \%)$ with $\mathrm{OMF}$ and a positive correlation with IMF. However, the slopes are substantially higher than those reported by Zieger et al. (2014) at Melpitz (Germany), namely, a slope of OMF with $\gamma$ of $-3.1 \pm 0.1$ with $R^{2}=0.57$ and a slope of IMF with $\gamma$ of $2.2 \pm 0.1$ $\left(R^{2}=0.57\right)$.

Similar tendencies were also reported by Zhang et al. (2015) at Lin'an, China, for OMF (slope of -1.20 and $R^{2}=0.88$ ) and IMF (slope of 0.93 and $R^{2}=0.57$ ). Similarly, Titos et al. (2014a) reported a slope of $-1.9\left(R^{2}=\right.$ $0.74)$ at an urban site in southern Spain. The in situ slope values are significantly lower compared with our results extrapolated to $\mathrm{RH}_{\mathrm{ref}}=40 \%$. These differences are likely due to the different measurement techniques. Since this is the first remote-sensing-based hygroscopicity study that includes chemical composition, this comparison is not straightforward. However, a clear tendency exists.

To identify the inorganic compound that plays a stronger role in aerosol hygroscopicity, we performed the calculation of the relative amount of $\mathrm{OA}\left(F_{\mathrm{o}}=C_{\mathrm{OA}} /\left(C_{\mathrm{OA}}+C_{\mathrm{IA}}\right)\right)$ against $\gamma$, where $C_{\mathrm{OA}}$ and $C_{\mathrm{IA}}$ are the mass concentrations 
Table 2. Linear fits of the extrapolated $f_{\beta}(85 / 40)$ versus OMF and IMF for the eight cases found. The values of the adjustments between $\gamma$ and OMF/IMF are also reported. Finally, regarding the amount of IA $\left(F_{\mathrm{O}}\right), F_{\mathrm{O}}$ is defined by $\left(\right.$ a) $F_{\mathrm{O}}=\mathrm{OA} /\left(\mathrm{OA}+\mathrm{SO}{ }_{4}^{2-}\right),(\mathrm{b}) F_{\mathrm{O}}=$ $\mathrm{OA} /\left(\mathrm{OA}+\mathrm{NO}_{3}^{-}\right)$, and (c) $F_{\mathrm{O}}=\mathrm{OA} /\left(\mathrm{OA}+\mathrm{SO}_{4}^{2-}+\mathrm{NO}_{3}^{-}\right)$and linearized versus $\gamma$.

\begin{tabular}{lrrc}
\hline & Slope & Intercept & $R^{2}$ \\
\hline$f_{\beta}(\mathrm{RH}=85 / 40)$ vs. $\mathrm{OMF}$ & $-4.81 \pm 0.04$ & $5.3 \pm 0.1$ & 0.60 \\
$f_{\beta}(\mathrm{RH}=85 / 40)$ vs. IMF & $3.8 \pm 0.1$ & $1.1 \pm 0.1$ & 0.40 \\
$\gamma$ vs. $\mathrm{OMF}$ & $-1.5 \pm 0.1$ & $1.5 \pm 0.1$ & 0.67 \\
$\gamma$ vs. $\mathrm{IMF}$ & $1.2 \pm 0.1$ & $0.2 \pm 0.1$ & 0.42 \\
$\gamma$ vs. $F_{\mathrm{O}}=\left(\mathrm{OA} /\left(\mathrm{OA}+\mathrm{SO}_{4}^{2-}\right)\right)$ & $-0.7 \pm 0.2$ & $1.2 \pm 0.2$ & 0.18 \\
$\gamma$ vs. $F_{\mathrm{O}}=\left(\mathrm{OA} /\left(\mathrm{OA}+\mathrm{NO}_{3}^{-}\right)\right)$ & $-1.3 \pm 0.1$ & $1.8 \pm 0.1$ & 0.32 \\
$\gamma$ vs. $F_{\mathrm{O}}=\left(\mathrm{OA} /\left(\mathrm{OA}+\mathrm{SO}_{4}^{2-}+\mathrm{NO}_{3}^{-}\right)\right)$ & $-1.2 \pm 0.2$ & $1.4 \pm 0.1$ & 0.40 \\
\hline
\end{tabular}
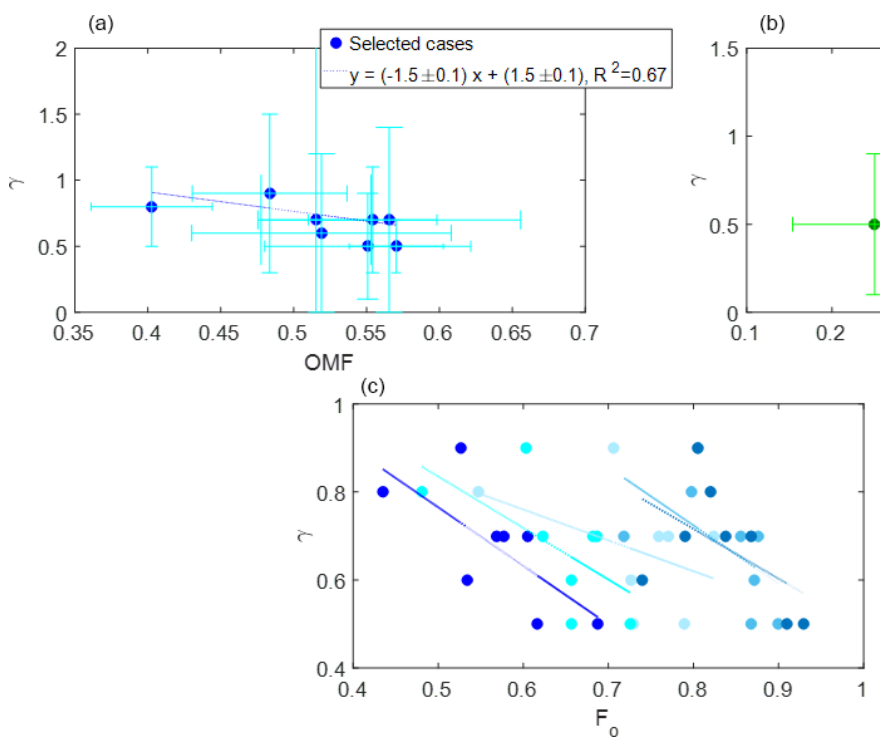
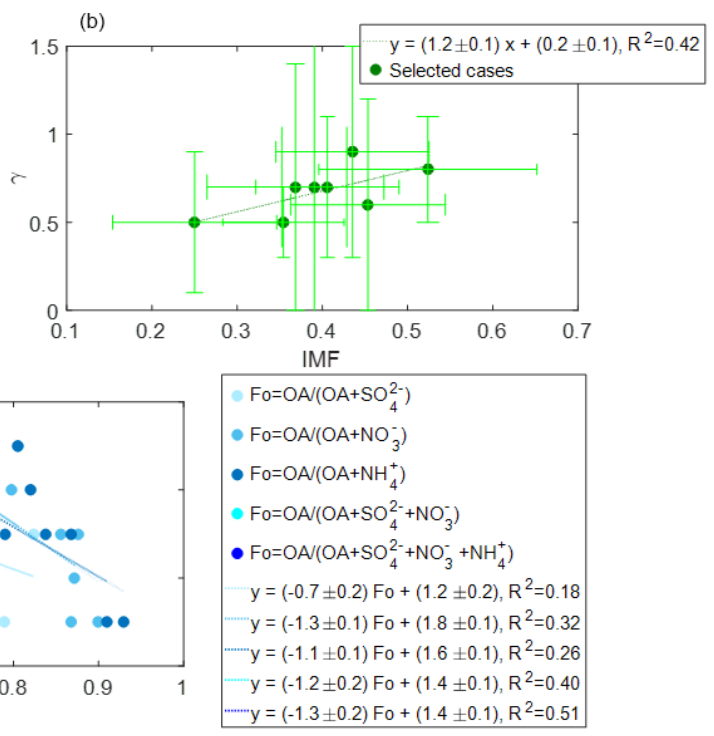

Figure 4. Mass fraction and $\gamma$ parameter correlation for the eight hygroscopic growth cases. (a) The OMF against $\gamma$ is noted in blue dots with error bars, and the dashed line is the linear fit; (b) the IMF and $\gamma$ correlation is noted in green dots with the respective error bars of the gamma and the OMF/IMF uncertainties, and the dashed line represents the linear fit; and (c) the correlations of the relative amount of OA and IA $\left(F_{\mathrm{O}}\right)$ versus $\gamma . F_{\mathrm{O}}$ is defined according to the legend.

of organic and inorganic aerosols, respectively. This calculation showed two different trends when $\mathrm{NO}_{3}^{-}$and $\mathrm{NH}_{4}^{+}$ were added, showing that $\mathrm{NO}_{3}^{-}$has a more pronounced negative correlation than $\mathrm{NH}_{4}^{+}$. The relative amount is determined by the calculation of $F_{\mathrm{O}}=\mathrm{OA} /\left(\mathrm{OA}+\mathrm{SO}_{4}^{2-}+\right.$ $\left.\mathrm{NO}_{3}^{-}\right)$with fitting line $y=(-1.2 \pm 0.2) F_{\mathrm{o}}+(1.4 \pm 0.1) R^{2}=$ 0.40 and $F_{\mathrm{o}}=\mathrm{OA} /\left(\mathrm{OA}+\mathrm{SO}_{4}^{2-}+\mathrm{NO}_{3}^{-}+\mathrm{NH}_{4}^{+}\right) y=(-1.3 \pm$ $0.2) F_{\mathrm{o}}+(1.4 \pm 0.1) R^{2}=0.51$. Then, we performed an individual calculation for each inorganic compound, and $F_{\mathrm{O}}=$ $\mathrm{OA} /\left(\mathrm{OA}+\mathrm{SO}_{4}^{2-}\right)$ showed the lowest correlation coefficient $\left(y=(-0.7 \pm 0.2) F_{\mathrm{o}}+(1.2 \pm 0.2), R^{2}=0.18\right)$, followed by $F_{\mathrm{O}}=\mathrm{OA} /\left(\mathrm{OA}+\mathrm{NH}_{4}^{+}\right)$with a slightly high correlation $(y=$ $\left.(-1.1 \pm 0.1) F_{\mathrm{o}}+(1.6 \pm 0.1) R^{2}=0.26\right)$. Then, the correlation increased for $F_{\mathrm{o}}=\mathrm{OA} /\left(\mathrm{OA}+\mathrm{NO}_{3}^{-}\right)\left(y=(-1.3 \pm 0.1) F_{\mathrm{o}}+\right.$ $\left.(1.8 \pm 0.1), R^{2}=0.32\right)$, suggesting that $\mathrm{NO}_{3}^{-}$is more determinant than other inorganic compounds at the ACTRIS
SIRTA station as an aerosol hygroscopic compound. The tendencies found can be compared with those obtained in Zhang et al. (2015) at Lin'an, China, where $\mathrm{NO}_{3}^{-}$played a stronger role than $\mathrm{SO}_{4}^{2-}$. These findings indicate that increases in $\mathrm{NO}_{3}^{-}$are associated with decreases in $\mathrm{SO}_{4}^{2-}$ by the Shanghai megacity influence.

\section{Conclusions and perspectives}

In this work, a new methodology was successfully applied to investigate aerosol hygroscopic growth based on a 4.5-year dataset obtained at the SIRTA observatory in the Paris region $\left(2.208^{\circ} \mathrm{E}, 48.713^{\circ} \mathrm{N}\right.$; $160 \mathrm{~m}$ a.s.1.). To our knowledge, this is the first time that such a study was conducted under unmodified atmospheric conditions using long-term in situ and ceilometer instrumentation. Among 107 potential cases 
of hygroscopic growth provided by the proposed procedure, 8 cases were clearly identified as fulfilling the strictly defined criteria to isolate events when the hygroscopic enhancement effect dominated all the other possible atmospheric processes.

The hygroscopic parameters were compared to online chemical composition measurements. All cases presented high concentrations of $\mathrm{OA}$, which is considered a background component over the study region. Hygroscopic growth properties were compared with previous remotesensing and in situ studies, and similar values for anthropogenic, polluted marine, and mixed particles (urban and suburban areas) were obtained.

The relationship between chemical composition and $\gamma$ parameter was evaluated, revealing that hygroscopicity backscattering enhancements decrease linearly as the contribution of organic aerosols increases. In this sense, the organic mass fraction (OMF) is anticorrelated with $\gamma$ and $f_{\beta}(\mathrm{RH}=85 / 40)$, while IMF shows a positive correlation with $\gamma$ and $f_{\beta}(\mathrm{RH}=85 / 40)$. This relationship of OMF and IMF is consistent with the literature; however, the magnitude of the trend varies among studies. These tendencies indicate that the role of IA is a determinant in the aerosol hygroscopic growth behavior. To determine the inorganic compound role, we calculated the contribution of $\mathrm{SO}_{4}^{2-}, \mathrm{NO}_{3}^{-}$, and $\mathrm{NH}_{4}^{+}$to the IA concentrations and demonstrated that $\mathrm{NO}_{3}^{-}$plays a more important role than other inorganic compounds in hygroscopic growth studies in this region.

As we evaluate the role of IA in aerosol hygroscopicity, it is important to conduct detailed studies on the role of OA given that these components can be soluble. Thus, further research on this topic may focus on the role of the different OA fractions, such as hydrocarbon-like organic, peat, and nonpeat biomass burning and oxygenated organic aerosols, in aerosol hygroscopic properties. A relevant aspect is associated with aerosol acidification that should be evaluated to determine the role of aged or fresh aerosols in hygroscopic properties and their impacts on OA. Finally, further investigation extending the study period is important to obtain statistically robust results over this region using automatic remote sensors.

Data availability. All datasets used in this paper are available upon request to the corresponding author.

Supplement. The supplement related to this article is available online at: https://doi.org/10.5194/acp-19-7883-2019-supplement.

Author contributions. AEBV, GT, and JABA designed and performed the experiments. GT ran the code. AEBV and JABA processed the ceilometer signal. OF and JEP prepared the in situ data.
AEBV wrote the manuscript with contributions from all the coauthors.

Competing interests. The authors declare that they have no conflict of interest.

Acknowledgements. This work was supported by the Andalusia Regional Government through project P12-RNM-2409; the Spanish Ministry of Economy and Competitiveness through projects CGL2013-45410-R, CGL2016-81092-R, and CGL2017-83538-C31-R; the Excellence network CGL2017-90884-REDT; the Juan de la Cierva grant IJCI-2016-29838; and the University of Granada trough the Plan Propio Program P9 Call-2013 contract and project UCE-PP2017. Andrés Esteban Bedoya-Velásquez has been supported by a grant for $\mathrm{PhD}$ studies in Colombia, COLCIENCIAS (Doctorado Nacional - 647), associated with the Physics Sciences program at the Universidad Nacional de Colombia, Sede Medellín, and the Asociación Universitaria Iberoamericana de Postgrado (AUIP). Financial support for EARLINET was provided through ACTRIS-2 Research Infrastructure Project EU H2O20 (grant agreement no. 654109), particularly for staying 2 weeks at SIRTA observatory and developing this investigation (TNA 3 SIR AHEAAARS). The authors gratefully acknowledge the FEDER program for the instrumentation used in this work. Juan Antonio Bravo-Aranda has received funding from the Marie Sklodowska-Curie Action Cofund 2016 EU project - Athenea3i under grant agreement no. 754446.

Review statement. This paper was edited by Matthias Tesche and reviewed by two anonymous referees.

\section{References}

Albrecht, B. A.: Aerosols, Cloud Microphysics, and Fractional Cloudiness, Science, 245, 1227-1230, 1989.

Bedoya-Velásquez, A. E., Navas-Guzmán, F., Granados-Muñoz, M. J., Titos, G., Román, R., Casquero-Vera, J. A., Ortiz-Amezcua, P., Benavent-Oltra, J. A., de Arruda Moreira, G., MontillaRosero, E., Hoyos, C. D., Artiñano, B., Coz, E., Olmo-Reyes, F. J., Alados-Arboledas, L., and Guerrero-Rascado, J. L.: Hygroscopic growth study in the framework of EARLINET during the SLOPE I campaign: synergy of remote sensing and in situ instrumentation, Atmos. Chem. Phys., 18, 7001-7017, https://doi.org/10.5194/acp-18-7001-2018, 2018.

Boucher, O., Randall, D., Artaxo, P., Bretherton, C., Feingold, G., Forster, P., Kerminen, V.-M., Kondo, Y., Liao, H., Lohmann, U., Rasch, P., Satheesh, S. K., Sherwood, S., Stevens, B., and Zhang, X. Y.: Clouds and Aerosols, in: Climate Change 2013: The Physical Science Basis. Contribution of Working Group I to the Fifth Assessment Report of the Intergovernmental Panel on Climate Change, edited by: Stocker, T. F., Qin, D., Plattner, G.-K., Tignor, M., Allen, S. K., Boschung, J., Nauels, A., Xia, Y., Bex, V., and Midgley, P. M., Cambridge University Press, Cambridge, UK and New York, NY, USA, 2013. 
Chen, J., Zhao, C. S., Ma, N., and Yan, P.: Aerosol hygroscopicity parameter derived from the light scattering enhancement factor measurements in the North China Plain, Atmos. Chem. Phys., 14, 8105-8118, https://doi.org/10.5194/acp-14-8105-2014, 2014.

Chen, J., Budisulistiorini, S. H., Miyakawa, T., Komazaki, Y., and Kuwata, M.: Secondary aerosol formation promotes water uptake by organic-rich wildfire haze particles in equatorial Asia, Atmos. Chem. Phys., 18, 7781-7798, https://doi.org/10.5194/acp18-7781-2018, 2018.

Covert, D. S., Charlson, R. J., and Ahlquist, N. C.: A study of the relationship of chemical composition and humidity to light scattering by aerosols, J. Appl. Meteorol., 11, 968-976, 1972.

Crenn, V., Sciare, J., Croteau, P. L., Verlhac, S., Fröhlich, R., Belis, C. A., Aas, W., Äijälä, M., Alastuey, A., Artiñano, B., Baisnée, D., Bonnaire, N., Bressi, M., Canagaratna, M., Canonaco, F., Carbone, C., Cavalli, F., Coz, E., Cubison, M. J., Esser-Gietl, J. K., Green, D. C., Gros, V., Heikkinen, L., Herrmann, H., Lunder, C., Minguillón, M. C., Močnik, G., O’Dowd, C. D., Ovadnevaite, J., Petit, J.-E., Petralia, E., Poulain, L., Priestman, M., Riffault, V., Ripoll, A., Sarda-Estève, R., Slowik, J. G., Setyan, A., Wiedensohler, A., Baltensperger, U., Prévôt, A. S. H., Jayne, J. T., and Favez, O.: ACTRIS ACSM intercomparison - Part 1: Reproducibility of concentration and fragment results from 13 individual Quadrupole Aerosol Chemical Speciation Monitors (Q-ACSM) and consistency with co-located instruments, Atmos. Meas. Tech., 8, 5063-5087, https://doi.org/10.5194/amt-8-50632015, 2015.

Drinovec, L., Močnik, G., Zotter, P., Prévôt, A. S. H., Ruckstuhl, C., Coz, E., Rupakheti, M., Sciare, J., Müller, T., Wiedensohler, A., and Hansen, A. D. A.: The "dual-spot" Aethalometer: an improved measurement of aerosol black carbon with realtime loading compensation, Atmos. Meas. Tech., 8, 1965-1979, https://doi.org/10.5194/amt-8-1965-2015, 2015.

Dupont, J.-C., Haeffelin, M., Badosa, J., Elias, T., Favez, O., Petit, J.-E., Meleux, F., Sciare, J., Crenn, V., and Bonne, J.-L.: Role of the boundary layer dynamics effects on an extreme air pollution event in Paris, Atmos. Environ., 141, 571-579, https://doi.org/10.1016/j.atmosenv.2016.06.061, 2016.

Feingold, G. and Morley, B.: Aerosol hygroscopic properties as measured by lidar and comparison with in situ measurements, J. Geophys. Res., 108, 4327, https://doi.org/10.1029/2002JD002842, 2003.

Fernández, A. J., Apituley, A., Veselovskii, I., Suvorina, A., Henzing, J., Pujadas, M., and Artiñano, B.: Study of aerosol hygroscopic events over Cabauw experimental site for atmospheric research (CESAR) using the multi-wavelength Raman lidar Caeli, Atmos. Environ., 120, 484-498, 2015.

Fernández, J., Molero, F., Becerril-Valle, M., Coz, E., Salvador, P., Artíñano, B., and Pujadas, M.: Application of remote sensing techniques to study aerosol water vapor uptake in a real atmosphere, Atmos. Res., 202, 112-127, https://doi.org/10.1016/j.atmosres.2017.11.020, 2018.

Ferrare, R. A., Melfi, S. H., Whiteman, D. N., Evans, K. D., and Leifer, R.: Raman lidar measurements of aerosol extinction and backscattering. 1. Methods and comparisons, J. Geophys. Res., 103, 19663-19672, 1998.

Freney, E., Zhang, Y., Croteau, P., Amodeo, T., Williams, L., Truong, F., Petit, J.-E., Sciare, J., Sarda-Estève, R., Bonnaire, N., Arumae, T., Aurela, M., Bougiatioti, E., Mihalopou- los, N., Coz, E., Artinano, B., Crenn, V., Elste, T., Heikkinen, L., Poulain, L., Wiedensohler, A., Herrmann, H., Priestman, M., Alastuey, A., Stavroulas, I., Tobler, A., Vasilescu, J., Zanca, N., Canagaratna, M., Carbone, C., Flentje, H., Green, D., Maasikmets, M., Marmureanu, L., Minguillon, M.C., Prévôt, A. S. H., Gros, V., Jayne, J. T., and Favez, O.: The second ACTRIS inter-comparison (2016) for Aerosol Chemical Speciation Monitors (ACSM): Calibration protocols and instrument performance evaluations, Aerosol Sci. Tech., https://doi.org/10.1080/02786826.2019.1608901, 2019.

Granados-Muñoz, M. J., Navas-Guzmán, F., Bravo-Aranda, J. A., Guerrero-Rascado, J. L., Lyamani, H., Valenzuela, A., Titos, G., Fernández-Gálvez, J., and Alados-Arboledas, L.: Hygroscopic growth of atmospheric aerosol particles based on active remote sensing and radiosounding measurements: selected cases in southeastern Spain, Atmos. Meas. Tech., 8, 705-718, https://doi.org/10.5194/amt-8-705-2015, 2015.

Haeffelin, M., Barthès, L., Bock, O., Boitel, C., Bony, S., Bouniol, D., Chepfer, H., Chiriaco, M., Cuesta, J., Delanoë, J., Drobinski, P., Dufresne, J.-L., Flamant, C., Grall, M., Hodzic, A., Hourdin, F., Lapouge, F., Lemaître, Y., Mathieu, A., Morille, Y., Naud, C., Noël, V., O’Hirok, W., Pelon, J., Pietras, C., Protat, A., Romand, B., Scialom, G., and Vautard, R.: SIRTA, a ground-based atmospheric observatory for cloud and aerosol research, Ann. Geophys., 23, 253-275, https://doi.org/10.5194/angeo-23-253-2005, 2005.

Haeffelin, M., Laffineur, Q., Bravo-Aranda, J.-A., Drouin, M.-A., Casquero-Vera, J.-A., Dupont, J.-C., and De Backer, H.: Radiation fog formation alerts using attenuated backscatter power from automatic lidars and ceilometers, Atmos. Meas. Tech., 9, 53475365, https://doi.org/10.5194/amt-9-5347-2016, 2016.

Hänel, G.: The Properties of Atmospheric Aerosol Particles as Functions of the Relative Humidity at Thermodynamic Equilibrium with the Surrounding Moist Air, in: Advances in Geophysics, edited by: Landsberg, H. E. and Mieghem, J. V., Academic Press, Inc., New York, USA, 73-188, 1976.

Jefferson, A., Hageman, D., Morrow, H., Mei, F., and Watson, T.: Seven years of aerosol scattering hygroscopic growth measurements from SGP: Factors influencing water uptake, J. Geophys. Res.-Atmos., 122, 9451-9466, https://doi.org/10.1002/2017JD026804, 2017.

Kamilli, K. A., Poulain, L., Held, A., Nowak, A., Birmili, W., and Wiedensohler, A.: Hygroscopic properties of the Paris urban aerosol in relation to its chemical composition, Atmos. Chem. Phys., 14, 737-749, https://doi.org/10.5194/acp-14-7372014, 2014.

Kotchenruther, R. A., Hobbs, P. V., and Hegg, D. A.: Humidification factors for atmospheric aerosol off the mid-Atlantic coast of United States, J. Geophys. Res., 104, 2239-2252, 1999.

Kotthaus, S., O'Connor, E., Münkel, C., Charlton-Perez, C., Haeffelin, M., Gabey, A. M., and Grimmond, C. S. B.: Recommendations for processing atmospheric attenuated backscatter profiles from Vaisala CL31 ceilometers, Atmos. Meas. Tech., 9, 37693791, https://doi.org/10.5194/amt-9-3769-2016, 2016.

Lv, M., Liu, D., Li, Z., Mao, J., Sun, Y., Wang, Z., Wang, Y., and Chenbo, X.: hygroscopic growth of atmospheric aerosol particles based on lidar, radiosonde, and in situ measurements: case studies from the Xinzhou field campaign, J. Quant. Spectrosc. Ra., 188, 60-70, 2017. 
Madonna, F., Amato, F., Vande Hey, J., and Pappalardo, G.: Ceilometer aerosol profiling versus Raman lidar in the frame of the INTERACT campaign of ACTRIS, Atmos. Meas. Tech., 8, 2207-2223, https://doi.org/10.5194/amt-8-2207-2015, 2015.

Navas-Guzmán, F., Fernández-Gálvez, J., Granados-Muñoz, M. J., Guerrero-Rascado, J. L., Bravo-Aranda, J. A., and AladosArboledas, L.: Tropospheric water vapour and relative humidity profiles from lidar and microwave radiometry, Atmos. Meas. Tech., 7, 1201-1211, https://doi.org/10.5194/amt-7-1201-2014, 2014.

Ng, N. L., Herndon, S. C., Trimborn, A., Canagaratna, M. R., Croteau, P. L., Onasch, T. B., Sueper, D., Worsnop, D. R., Zhang, Q., and Sun, Y. L.: An aerosol chemical speciation monitor (ACSM) for routine monitoring of the composition and mass concentrations of ambient aerosol, Aerosol Sci. Tech., 45, 780 794, 2011

Pappalardo, G., Amodeo, A., Apituley, A., Comeron, A., Freudenthaler, V., Linné, H., Ansmann, A., Bösenberg, J., D’Amico, G., Mattis, I., Mona, L., Wandinger, U., Amiridis, V., AladosArboledas, L., Nicolae, D., and Wiegner, M.: EARLINET: towards an advanced sustainable European aerosol lidar network. Atmos. Meas. Tech., 7, 2389-2409, https://doi.org/10.5194/amt7-2389-2014, 2014.

Petit, J.-E., Favez, O., Sciare, J., Canonaco, F., Croteau, P., Močnik, G., Jayne, J., Worsnop, D., and Leoz-Garziandia, E.: Submicron aerosol source apportionment of wintertime pollution in Paris, France by double positive matrix factorization (PMF2) using an aerosol chemical speciation monitor (ACSM) and a multiwavelength Aethalometer, Atmos. Chem. Phys., 14, 1377313787, https://doi.org/10.5194/acp-14-13773-2014, 2014.

Petit, J.-E., Favez, O., Sciare, J., Crenn, V., Sarda-Estève, R., Bonnaire, N., Močnik, G., Dupont, J.-C., Haeffelin, M., and LeozGarziandia, E.: Two years of near real-time chemical composition of submicron aerosols in the region of Paris using an Aerosol Chemical Speciation Monitor (ACSM) and a multiwavelength Aethalometer, Atmos. Chem. Phys., 15, 2985-3005, https://doi.org/10.5194/acp-15-2985-2015, 2015.

Petit, J.-E., Amodeo, T., Meleux, F., Bessagnet, B., Menut, L., Grenier, D., Pellan, Y., Ockler, A., Rocq, B., and Gros, V.: Characterising an intense PM pollution episode in March 2015 in France from multi-site approach and near real time data: Climatology, variabilities, geographical origins and model evaluation, Atmos. Environ., 155, 68-84, 2017.

Pilinis, C. and Pandis, S. N.: Physical, Chemical and Optical Properties of Aerosols, in: The Handbook of Environmental Chemistry, edited by: Huntzinger, O., Springer Verlag, Heidelberg, Germany, 99-124, 1995.

Putaud, J.-P., Van Dingenen, R., Alastuey, A., Bauer, H., Birmili, W., Cyrys, J., Flentje, H., Fuzzi, S., Gehrig, R., Hansson, H. C., Harrison, R. M., Herrmann, H., Hitzenberger, R. , Huglin, C., Jones, A. M., Kasper-Giebl, A., Kiss, G., Kousa, A., Kuhlbusch, T. A. J., Loschau, G., Maenhaut, W., Molnar, A., Moreno, T., Pekkanen, J., Perrino, C., Pitz, M., Puxbaum, H., Querol, X., Rodriguez, S., Salma, I., Schwarz, J., Smolik, J., Schneider, J., Spindler, G., ten Brink, H., Tursic, J., Viana, M., Wiedensohler, A., and Raes, F.: A European aerosol phenomenology - 3: Physical and chemical characteristics of particulate matter from 60 rural, urban, and kerbside sites across Europe, Atmos. Environ., 44, 1308-1320, 2010.
Randriamiarisoa, H., Chazette, P., Couvert, P., Sanak, J., and Mégie, G.: Relative humidity impact on aerosol parameters in a Paris suburban area, Atmos. Chem. Phys., 6, 1389-1407, https://doi.org/10.5194/acp-6-1389-2006, 2006.

Rosati, B., Wehrle, G., Gysel, M., Zieger, P., Baltensperger, U., and Weingartner, E.: The white-light humidified optical particle spectrometer (WHOPS) - a novel airborne system to characterize aerosol hygroscopicity, Atmos. Meas. Tech., 8, 921-939, https://doi.org/10.5194/amt-8-921-2015, 2015.

Rosati, B., Herrmann, E., Bucci, S., Fierli, F., Cairo, F., Gysel, M., Tillmann, R., Größ, J., Gobbi, G. P., Di Liberto, L., Di Donfrancesco, G., Wiedensohler, A., Weingartner, E., Virtanen, A. Mentel, T. F., and Baltensperger, U.: Studying the vertical aerosol extinction coefficient by comparing in situ airborne data and elastic backscatter lidar, Atmos. Chem. Phys., 16, 4539-4554, https://doi.org/10.5194/acp-16-4539-2016, 2016.

Sheridan, P. J., Jefferson, A., and Ogren, J. A.: Spatial variability of submicrometer aerosol radiative properties over the Indian Ocean during INDOEX, J. Geophys. Res., 107, 8011, https://doi.org/10.1029/2000JD000166, 2002.

Sorooshian, A., Hersey, S., Brechtel, F. J., Corless, A., Flagan, R. C., and Seinfeld, J. H.: Size-Resolved Aerosol Hygroscopic Growth Measurements: Differential Aerosol Sizing and Hygroscopicity Spectrometer Probe (DASH-SP), Aerosol. Sci. Tech., 42, 445-464, https://doi.org/10.1080/02786820802178506, 2008.

Swietlicki, E., Hansson, H. C., Hämeri, K., Svenningsson, B., Massling, A., Mcfiggans, G., Mcmurry, P. H., Petäjä, T., Tunved, P., Gysel, M., Topping, D., Weingartner, E., Baltensperger, U., Rissler, J., Wiedensohler, A., and Kulmala, M.: Hygroscopic properties of submicrometer atmospheric aerosol particles measured with H-TDMA instruments in various environments - a review, Tellus B, 6, 432-469, 2008.

Titos, G., Lyamani, H., Cazorla, A., Sorribas, M., FoyoMoreno, I., Wiedensohler, A., and Alados-Arboledas, L.: Study of the relative humidity dependence of aerosol light-scattering in southern Spain, Tellus B, 66, 24536, https://doi.org/10.3402/tellusb.v66.24536, 2014a.

Titos, G., Jefferson, A., Sheridan, P. J., Andrews, E., Lyamani, H., Alados-Arboledas, L., and Ogren, J. A.: Aerosol light-scattering enhancement due to water uptake during the TCAP campaign, Atmos. Chem. Phys., 14, 7031-7043, https://doi.org/10.5194/acp-14-7031-2014, 2014b.

Titos, G., Cazorla, A., Zieger, P., Andrews, E., Lyamani, H., Granados- Muñoz, M. J., Olmo, F. J., and Alados-Arboledas, L.: Effect of hygroscopic growth on the aerosol light-scattering coefficient: A review of measurements, techniques and error sources, Atmos. Environ., 141, 494-507, 2016.

Twomey, J.: the influence of pollution on the shortwave albedo of clouds, Atmos. Sci., 34, 1149-1152, 1977.

Veselovskii, I., Whiteman, D. N., Kolgotin, A., Andrews, E., and Korenskii, M.: Demonstration of aerosol property profiling by multi-wavelength lidar under varying relative humidity conditions, J. Atmos. Ocean. Tech., 26, 1543-1557, 2009.

Wiegner, M. and Gasteiger, J.: Correction of water vapor absorption for aerosol remote sensing with ceilometers, Atmos. Meas. Tech., 8, 3971-3984, https://doi.org/10.5194/amt-8-3971-2015, 2015. 
Wiegner, M. and Geiß, A.: Aerosol profiling with the Jenoptik ceilometer CHM15kx, Atmos. Meas. Tech., 5, 1953-1964, https://doi.org/10.5194/amt-5-1953-2012, 2012.

Wiegner, M., Mattis, I., Pattantyús-Ábrahám, M., Bravo-Aranda, J. A., Poltera, Y., Haefele, A., Hervo, M., Görsdorf, U., Leinweber, R., Gasteiger, J., Haeffelin, M., Wagner, F., Cermak, J., Komínková, K., Brettle, M., Münkel, C., and Pönitz, K.: Aerosol backscatter profiles from ceilometers: validation of water vapor correction in the framework of CeiLinEx2015, Atmos. Meas. Tech., 12, 471-490, https://doi.org/10.5194/amt-12-4712019, 2019.

Zhang, L., Sun, J. Y., Shen, X. J., Zhang, Y. M., Che, H., Ma, Q. L., Zhang, Y. W., Zhang, X. Y., and Ogren, J. A.: Observations of relative humidity effects on aerosol light scattering in the Yangtze River Delta of China, Atmos. Chem. Phys., 15, 84398454, https://doi.org/10.5194/acp-15-8439-2015, 2015.

Zhang, Q., Jimenez, J. L., Canagaratna, M. R., Allan, J. D., Coe, H., Ulbrich, I., Alfarra, M. R., Takami, A., Middlebrook, A. M., Sun, Y. L., Dzepina, K., Dunlea, E., Docherty, K., DeCarlo, P. F., Salcedo, D., Onasch, T., Jayne, J. T., Miyoshi, T., Shimono, A., Hatakeyama, S., Takegawa, N., Kondo, Y., Schneider, J., Drewnick, F., Borrmann, S., Weimer, S., Demerjian, K., Williams, P., Bower, K., Bahreini, R., Cottrell, L., Griffin, R. J., Rautiainen, J., Sun, J. Y., Zhang, Y. M., and Worsnop, D. R.: Ubiquity and dominance of oxygenated species in organic aerosols in anthropogenically-influenced Northern Hemisphere midlatitudes, Geophys. Res. Lett., 34, L13801, https://doi.org/10.1029/2007GL029979, 2007.
Zieger, P., Weingartner, E., Henzing, J., Moerman, M., de Leeuw, G., Mikkilä, J., Ehn, M., Petäjä, T., Clémer, K., van Roozendael, M., Yilmaz, S., Frieß, U., Irie, H., Wagner, T., Shaiganfar, R., Beirle, S., Apituley, A., Wilson, K., and Baltensperger, U.: Comparison of ambient aerosol extinction coefficients obtained from in-situ, MAX-DOAS and LIDAR measurements at Cabauw, Atmos. Chem. Phys., 11, 2603-2624, https://doi.org/10.5194/acp11-2603-2011, 2011.

Zieger, P., Fierz-Schmidhauser, R., Poulain, L., Müller, T., Birmili, W., Spindler, G., Wiedensohler, A., Baltensperger, U., and Weingartner, E.: Influence of water uptake on the aerosol particle light scattering coefficients of the Central European aerosol, Tellus B, 66, 22716, https://doi.org/10.3402/tellusb.v66.22716, 2014. 